\title{
Do spatial differences in the abundance of two serranid fishes in estuaries of tropical Australia reflect long-term salinity patterns?
}

\author{
Marcus Sheaves* \\ Department of Marine Biology, James Cook University of North Queensland, 4811 Townsville, Australia
}

\begin{abstract}
Epinephelus coioides and E. malabaricus are closely related species of serranid fishes. They are similar in appearance, occupy the same habitats and are represented in estuaries of northeastern tropical Australia almost entirely by juveniles. Fish traps were used to sample these 2 species from 3 estuaries on the northeast coast of tropical Australia over a 2 yr period. Patterns of distribution, abundance and size structure were compared. Despite the similarities between the 2 species, they showed quite different patterns of distribution and abundance, both within and between estuaries. In seaward parts of the estuaries the numbers of $E$. coioides were similar to or greater than those of $E$. malabaricus. However, in upstream areas E. malabaricus became much more abundant than E. coioides. The reasons for this change in dominance are unknown. However, upstream areas of the estuaries exhibited extreme levels of salinity (either hypersaline or hyposaline) and catches of the 2 species correlated with the maximum deviation in salinity. This suggests that if salinity, or some correlated variable, does influence the abundance of the 2 species, it is through long-term effects rather than shortterm changes. Regardless of the reason, these spatial differences in abundance suggest that $E$. malabaricus is better equipped to deal with the challenges of estuary life than is E. coioides.
\end{abstract}

KEY WORDS: Estuary · Tropical Fish distribution - Salinity

\section{INTRODUCTION}

Serranid fishes of the genus Epinephelus occur in estuaries throughout tropical Australia (Collette 1983, Blaber et al. 1985, Blaber et al. 1989, Sheaves 1992, 1993, 1995a). The species reported most commonly from estuaries in tropical Australia are E. malabaricus, E. tauvina, E. coioides and E. suillus. However, much confusion has existed in the classification of fishes of this genus (Randall \& Ben-Tuvia 1983, Randall 1987. Randall \& Heemstra 1991). It appears that most reports of Epinephelus from estuaries in this area refer to 2 species, E. coioides and E. malabaricus. E. suillus is a synonym of $E$. coioides (Randall \& Heemstra 1991), and both species have often been misidentified as $E$. tauvina (Randall \& Heemstra 1991) which is a species typical of clear-water coral reef areas rather than estu-

\footnotetext{
•E-mail: marcus.sheaves@jcu.edu.au
}

aries (Randall et al. 1990). E. coioides and E. malabaricus are common within estuaries of tropical eastern Australia where, despite occurring to sizes of $400 \mathrm{~mm}$ fork length or more (Sheaves 1992, 1993, 1995a), the populations of both species consist almost entirely of pre-reproductive females (Sheaves 1995b).

The distribution of Epinephelus coioides and E. malabaricus within and between estuaries has received little study. However, in Alligator Creek, an estuary on the coast of tropical northeastern Australia, E. coioides and E. malabaricus were found to possess quite different spatial distributions (Sheaves 1992). E. coioides was the dominant serranid in downstream areas, but catches declined in upstream areas of the creek. E. malabaricus showed the opposite pattern with numbers increasing from the lower parts of the creek to upstream areas, where this species became the dominant serranid. If the differences in distribution, abundance and dominance of these congenerics are general patterns in estuaries in tropical Australia, it suggests 
underlying differences in the biology of the 2 species, possibly in the way they respond to physical conditions in estuaries.

To determine whether the interspecific differences noted by Sheaves (1992) existed in other estuaries in northeastern tropical Australia and whether such patterns were maintained over time, I compared the distributions, abundances and size structures of Epinephelus coioides and E. malabaricus within 3 estuaries on the coast of tropical northeastern Australia (Alligator, Barramundi and Cattle Creeks) over a 2 yr period. Spatial patterns of distributions and abundances of the 2 species were distinctly different, and the relationship between these differences and variations in water temperature and salinity was investigated.

\section{MATERIALS AND METHODS}

Study sites. Sampling was conducted at Cattle $\left(18^{\circ}\right.$ $\left.15^{\prime} \mathrm{S}, 146^{\circ} 15^{\prime} \mathrm{E}\right)$, Barramundi (19 $\left.29^{\circ} \mathrm{S}, 147^{\circ} 10^{\prime} \mathrm{E}\right)$ and Alligator Creeks $\left(19^{\circ} 20^{\prime} \mathrm{S}, 146^{\circ} 55^{\prime} \mathrm{E}\right), 3$ mangrove-lined estuarics on the nor theastern coast of tropical Australia (Fig. 1). The 3 creeks have quite different rainfall patterns. Cattle Creek lies at the southern extremity of the 'wet tropics' and its catchment receives a considerably higher annual rainfall than areas around the other 2 creeks, both of which lje in the dry tropics (Oliver 1978). While the average annual run-off in the catchment area of Cattle Creek exceeds 1000 mm (Bonell 1983), for Alligator Creek annual runoff is about $500 \mathrm{~mm}$ and for Barramundi Creek is less than $375 \mathrm{~mm}$ (Bonell 1983).

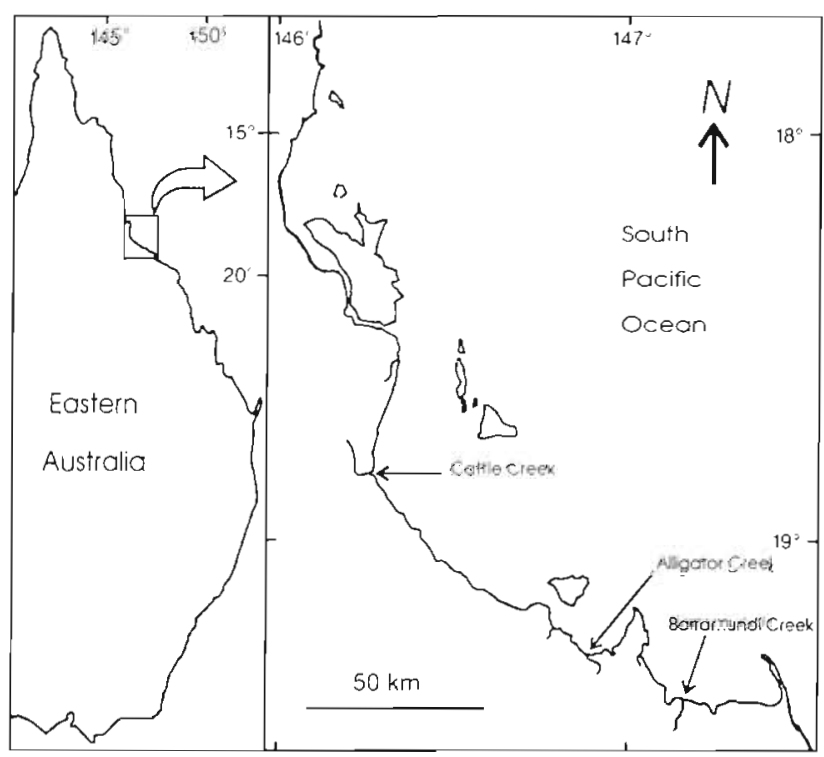

Fig. 1. Locations of Cattle, Barramundi and Alligator Creeks
Sampling. Sampling was conducted using 12 Antillean- $Z$ fish traps $(1800 \mathrm{~mm}$ long, $1100 \mathrm{~mm}$ wide, $600 \mathrm{~mm}$ high, plan area approx. $1.53 \mathrm{~m}^{2}$, volume approx. $0.92 \mathrm{~m}^{3}$ ) with $12.5 \mathrm{~mm}$ square galvanised steel mesh and straight entrance funnels, and baited with $500 \mathrm{~g}$ of Western Australian blue pilchards Sardinops neopilchardus. These traps and related sampling protocols are described in Sheaves (1995a).

The navigable portions of Cattle Creek and Barramundi Creek (lower $15 \mathrm{~km}$ ) were each divided arbitrarily into 4 regions (Bottom, Lower, Upper, Top) representing increasing distance upstream. Each of these regions was approximately $3240 \mathrm{~m}$ in length and separated from the adjacent region by a gap of about $500 \mathrm{~m}$. As Alligator Creek had a shorter navigable length only the Bottom and Lower regions were defined. Three traps were used to sample in each region, with no trapping site being used more than once during the study.

Three days of sampling were conducted during the first quarter of the lunar cycle for 24 consecutive cycles, between October 14, 1991 and August 25, 1993. One creek was sampled in each Iunar cycle. To enable data to be collected from each creek at a constant interval of 3 lunar cycles, the creeks were always sampled in the same order, first Cattle Creek then Barramundi Creek then Alligator Creek. Thus each creek was sampled on 8 accasions, 3 mo apart. On each occasion, 3 traps were used in each region for $3 d$ with 2 daytime samples and 1 overnight sample collected from each trap on each day. Although comparing systems sampled in different months has the potential to produce biased results, logistic constraints made this unavoidable. However, the nature and consistency of the patterns found during this study suggests that any such biases are unlikely to be important.

The groups of successive samples from the 3 creeks over a 3 mo period (i.e. Cattle, Barramundi then Alligator) were considered to constitute a season for the purposes of these analyses. However, as there was no gap separating the 'seasons' this division was wholly arbitrary and served only to group the samples broadly into units for temporal comparisons. The seasons were designated as follows: Spring 1991 (October/November/December 1991), Summer 1992 (January/February/.1arch 1992), Autumn 1992 (April/May/June 1992), Winter 1992 (July/August/September 1992), Spring 1992 (October/November/December 1992), Summer 1993 (January/February/early March 1993), Autumn 1993 (late March/April/May 1993), Winter 1993 (June/July/August 1993).

Data analysis. Because only the 2 most seaward regions (Bottom and Lower) could be defined in Alligator Creek the data for Epinephelus coioides and E. malabaricus were analysed in 2 phases; all regions of 
Cattle and Barramundi Creeks (Analysis I), and the lower 2 regions of all 3 creeks (Analysis II)

Previous studies (Sheaves 1992, 1993, 1995a) suggested that Epinephelus coioides and E. malabaricus would be trapped in low numbers only. Thus it was decided a priorj to pool data over sites, soaks and days. Data from day and night soaks were pooled also. Thus the data analysed consisted of fish lengths or numbers of fishes in each region of each creek for each season.

Size. Analysis of variance (ANOVA) was used to investigate changes in the mean fork length (FL) of Epinephelus coioides and E. Malabaricus. The factors analysed (Seasons, Creeks, Regions) were considered fixed and orthogonal to each other.

As expected many catch rates were low, with no fish of one or another species being trapped in a number of Season $\times$ Creek $\times$ Region combinations. Due to this paucity of data, particular factor levels were omitted from the analyses of size. For Epinephelus coioides, Analysis I included data from the 3 lower regions of Barramundi Creek only, and Analysis II included data from the 2 seaward regions (Bottom and Lower) of Barramundi and Alligator Creeks for all seasons except Winter 1992. For E. malabaricus, Analysis I included data for the Bottom, Lower and Upper regions of Barramundi and Cattle Creeks for all seasons, and Analysis II included data for the 2 seaward regions of Barramundi and Alligator Creeks in all seasons except Winter 1993.

Plots of residuals against predicted values and normal probability plots showed no evidence of heterogeneity of variance or non-normality in the data for Epinephelus coioides or the data for E. malabaricus from Cattle and Barramundi Creeks. However, in the data for E. malabaricus from the 2 lower regions of all creeks (Analysis II) there was a tendency for the residuals to increase with the mean, indicating heterogeneity of variance. Therefore a square root transformation was applied to these E. malabaricus data resulting in a distribution of residuals that showed no evidence of heterogeneity of variance.

Distribution and abundance. To enable the abundances of Epinephelus coioides and E. malabaricus to be compared the numbers of the 2 species were analysed together. As a number of Season $\times$ Creek $\times$ Region combinations produced no fish of one or another species, the data were pooled over seasons and only the spatial factors (Creek and Region) analysed. The data in the form of a 3 -way contingency table (Species $\times$ Creek $x$ Region) were analysed using a log-linear model.
Physical variables. On each sampling day the surface and bottom temperatures and salinities of each region were measured as close to low tide as possible. As bottom and surface values were highly correlated only bottom values were analysed. These were thought to better represent the physical conditions the fish would have been exposed to. The absolute value of the maximum deviation in salinity (MSD) away from mean 'normal' seawater salinity ( $35 \%$; Kalle 1971) was calculated for each region of each creek and the relationship between catches of Epinephelus coioides and E. malabaricus, and bottom temperature, bottom salinity and MSD determined.

\section{RESULTS}

\section{Size}

During the course of the study 280 Epinephelus coioides between 120 and $500 \mathrm{~mm}$ FL and 334 E. malabaricus between 122 and $619 \mathrm{~mm}$ FL were trapped in Cattle, Barramundi and Alligator Creeks. The overall size structures of $E$. coioides and E. malabaricus (Fig. 2) displayed some differences. The maximum size of $E$. coioides $(500 \mathrm{~mm}$ ) was much smaller than that of E. malabaricus $(619 \mathrm{~mm})$. Furthermore, for E. coioides only $3.2 \%$ of fish were greater than $400 \mathrm{~mm}$ and only 1 fish was over $460 \mathrm{~mm}$, while for E. malabaricus $16.2 \%$ of fish were greater than $400 \mathrm{~mm}$. While both species showed a broad mode beginning at around $250 \mathrm{~mm}$, the mode for E. malabaricus extended to

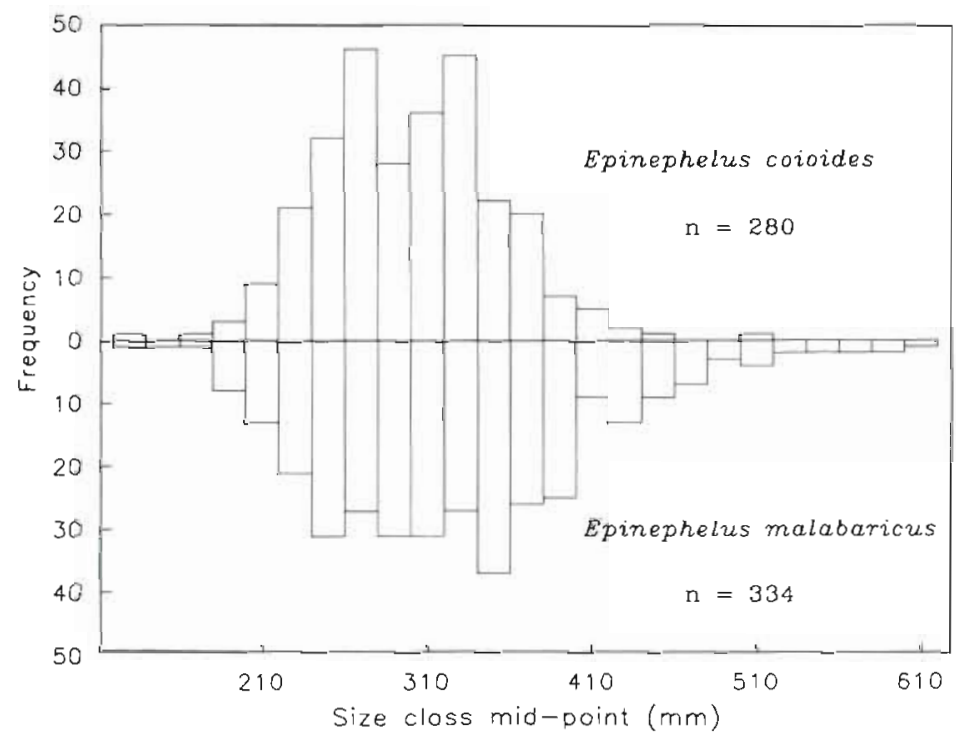

Fig. 2. Comparison of size structures (fork length) of Epinephelus coioides and $E$. malabaricus from estuaries in northeastern Australia 
Table 1. Epinephelus coioides. Analysis of variance tables for the mean fork length of individuals in 2 estuaries. (a) Three regions in Barramundi. Creek (Analysis 1), (b) two regions in Barramundi and Alligator Creeks (Analysis II). -: factors not analysed

\begin{tabular}{|c|c|c|c|c|c|c|}
\hline \multirow[t]{2}{*}{ Source of variation } & \multicolumn{3}{|c|}{$-(a)$} & \multicolumn{3}{|c|}{ (b) } \\
\hline & $\begin{array}{l}\text { df of } \\
\text { Fratio }\end{array}$ & $F$ & $\mathrm{p}$ & $\begin{array}{c}\text { df of } \\
\text { Fratio }\end{array}$ & $F$ & $\mathrm{p}$ \\
\hline Creek & - & - & - & $1 / 190$ & 1.32 & 0.252 \\
\hline Region & $2 / 101$ & 0.46 & 0.634 & $1 / 190$ & 0.01 & 0.938 \\
\hline Season & $6 / 101$ & 1.78 & 0.111 & $6 / 190$ & 2.07 & 0.059 \\
\hline Creek $\times$ Region & - & - & - & $1 / 190$ & 2.04 & 0.155 \\
\hline Creek $\times$ Season & - & - & - & $6 / 190$ & 0.52 & 0.796 \\
\hline Region $\times$ Season & $12 / 101$ & 1.16 & 0.321 & $6 / 190$ & 1.94 & 0.076 \\
\hline Creek $\times$ Region $\times$ Season & - & - & - & $6 / 190$ & 0.61 & 0.722 \\
\hline
\end{tabular}

about $390 \mathrm{~mm}$, while for $E$. coioides the mode extended to about $330 \mathrm{~mm}$ only. The lower ends of the distributions were similar for both species, falling off rapidly from aboul $250 \mathrm{~mm}$ lo a ininimum of about $120 \mathrm{~mm}$.

There were no clear differences between the fork lengths of Epinephelus coioides for any of the variables (Table 1) for Analysis I (3 seaward regions of Barramundi Creek) or Analysis II (the 2 seaward regions of Barramundi and Alligator Creeks), although there was weak evidence of differences between seasons in Analysis II

For Epinephelus malabaricus season had an independent effect on fork length for both Analysis I (3 seaward regions of Cattle and Barramundi Creeks) and Analysis II (2 seaward regions of all 3 creeks) (Table 2). Creek and Region interacted strongly in Analysis I. While there was a very strong Creek effect in Analysis II there was no evidence of differences due to Region (Table 2).

While the mean fork length of Epinephelus malabaricus in Cattle and Barramundi Creeks differed with season (Fig. 3), there was no clear pattern; each of the peaks of fork length occurred in different seasons. Size frequency plots of E. malabaricus over the 8 seasons also lacked any consistent patterns, as did fork lengths in the 2 lower regions of Cattle, Alligator and Barramundi Creeks.
The mean fork length of Epinephelus malabaricus was clearly larger in the Bottom and Lower regions of Barramundi Creek than in the corresponding regions of Cattle Creck (Table 2a; Fig. 4). Howcvor, in the Upper region the mean fork length was greater in Cat-

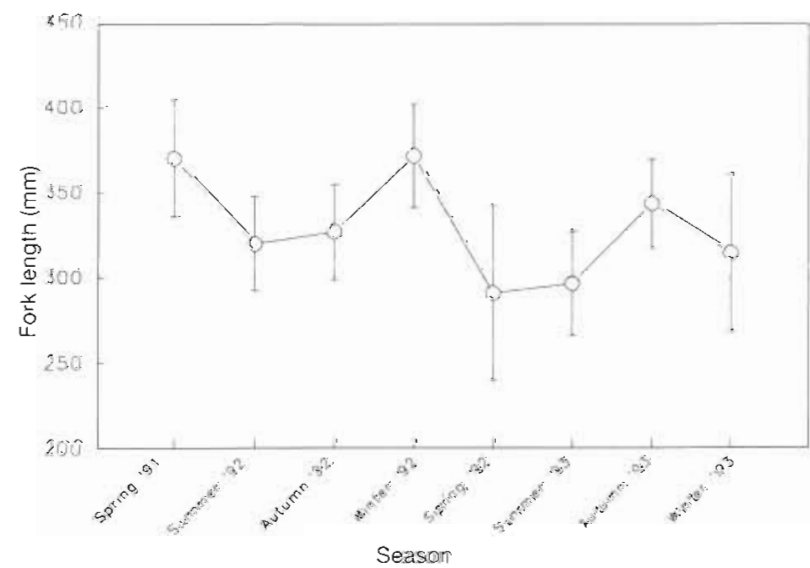

Fig. 3. Epinephelus malabaricus. Differences in fork length over 2 yr. Data are means $\pm 95 \%$ confidence intervals

Table 2. Epinephelus coioldes. Analysis of variance tables for the fork length of individuals in 3 estuaries. (a) Three regions in Cattle and Barramundi Creeks (Analysis I), (b) two regions in Cattle, Barramundi and Alligator Creeks (Analysis II). Bold values indicate significant effects

\begin{tabular}{|c|c|c|c|c|c|c|}
\hline \multirow[t]{2}{*}{ Source of variation } & \multicolumn{3}{|c|}{$\longrightarrow(\mathrm{a}) \longrightarrow$} & \multicolumn{3}{|c|}{- (b) } \\
\hline & $\begin{array}{l}\text { df of } \\
\text { Fratio }\end{array}$ & $F$ & $p$ & $\begin{array}{l}\text { df of } \\
\text { Fratio }\end{array}$ & F & $\mathrm{p}$ \\
\hline Creek & $1 / 171$ & 0.35 & 0.556 & $2 / 189$ & 14.77 & 0.000 \\
\hline Region & $2 / 171$ & 0.95 & 0.389 & $1 / 189$ & 0.321 & 0.578 \\
\hline Season & $7 / 171$ & 2.46 & 0.020 & $6 / 189$ & 2.865 & 0.011 \\
\hline Creek $\times$ Region & $2 / 171$ & 7.72 & 0.001 & $2 / 189$ & 1.336 & 0.265 \\
\hline Creek $\times$ Season & $7 / 171$ & 1.34 & 0.234 & $12 / 189$ & 1263 & 0.244 \\
\hline Region $\times$ Season & $14 / 171$ & 1.42 & 0.148 & $6 / 189$ & 0.592 & 0.726 \\
\hline Creek $\times$ Region $\times$ Season & $14 / 171$ & 1.09 & 0.370 & $12 / 189$ & 0.695 & 0.755 \\
\hline
\end{tabular}




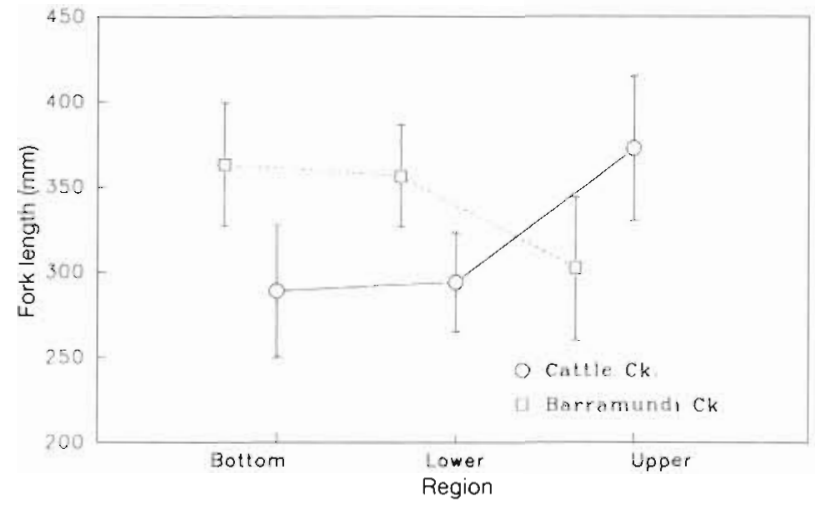

Fig. 4. Epinephelus malabaricus. Effect of the interaction between Creek and Region on the tork length of individuals in Cattle and Barramundi Creeks. Duta are means $\pm 95 \%$ confidence intervals

tle Creek than in Barramundi Creek (Tukey's test: $\left.q_{171,6}=4.247, p<0.05\right)$. Size frequency plots for this interaction (Fig. 5) showed that in the regions with small mean sizes (Bottom and Lower regions of Cattle Creek and Upper region of Barramundi Creek) a small proportion of large E. malabaricus were trapped, compared to the Bottom and Lower regions of Barramundi
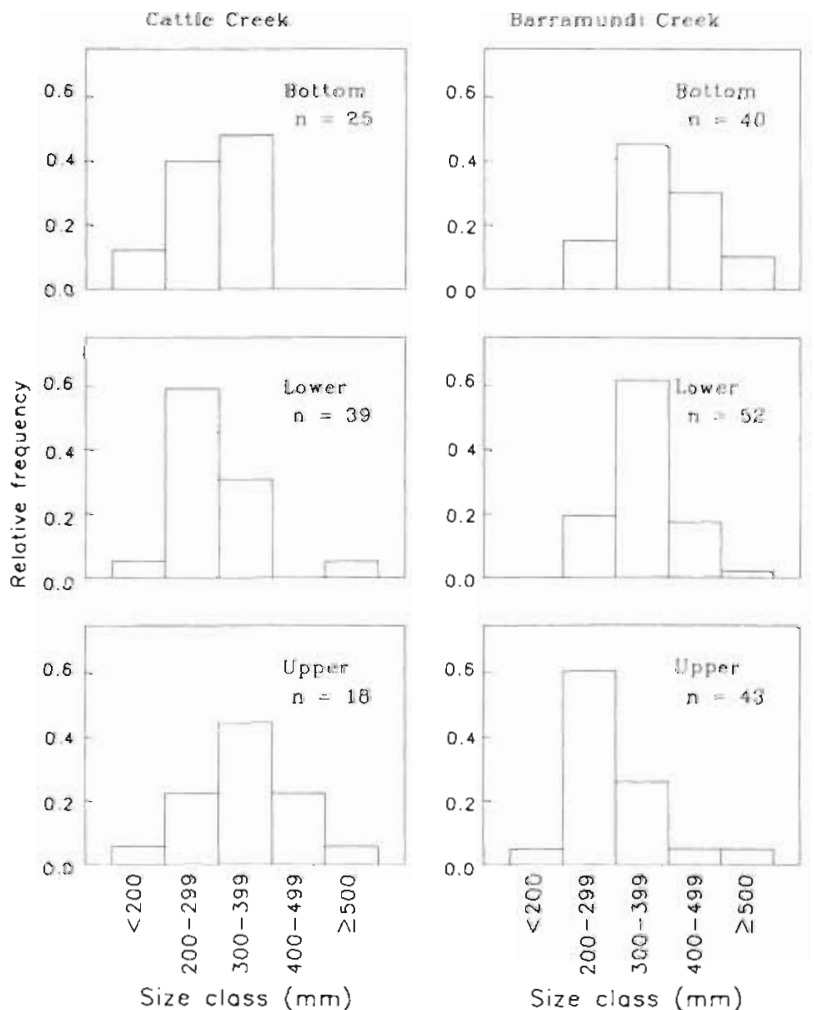

Fig. 5. Epinephelus malabaricus. Size frequency plots for the interaction between Creek and Region on the fork length of individuals shown in Fig. 4
Creek and the Upper region of Cattle Creek. When the 2 lower regions of Cattle, Alligator and Barramundi Creeks (Table 2b) were compared the mean fork length was larger in Barramundi Creek than in either Cattle Creek or Alligator Creek where the mean sizes were similar (Fig. 6). Size frequency comparisons between creeks (Fig. 7) showed that while Cattle and Barramundi Creeks produced a similar range of sizes

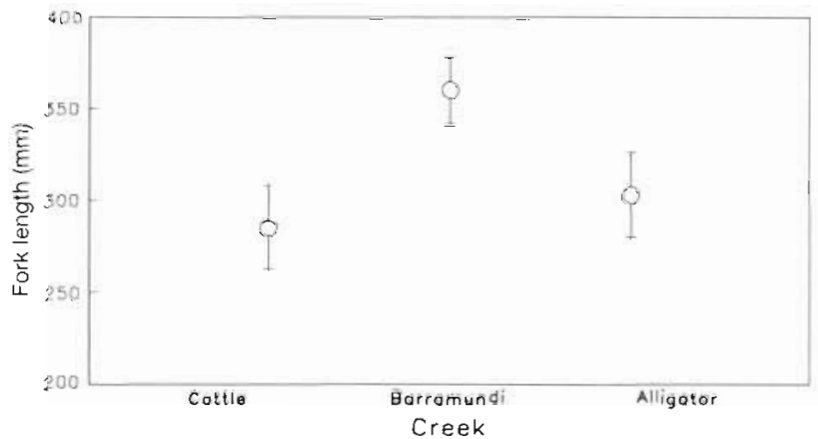

Fig. 6. Epinephelus malabaricus. Comparison of the fork lengths of individuals in the 2 seaward regions of Cattle, Barramundi and Alligator Creeks. Data are means $\pm 95 \%$ confidence intervals
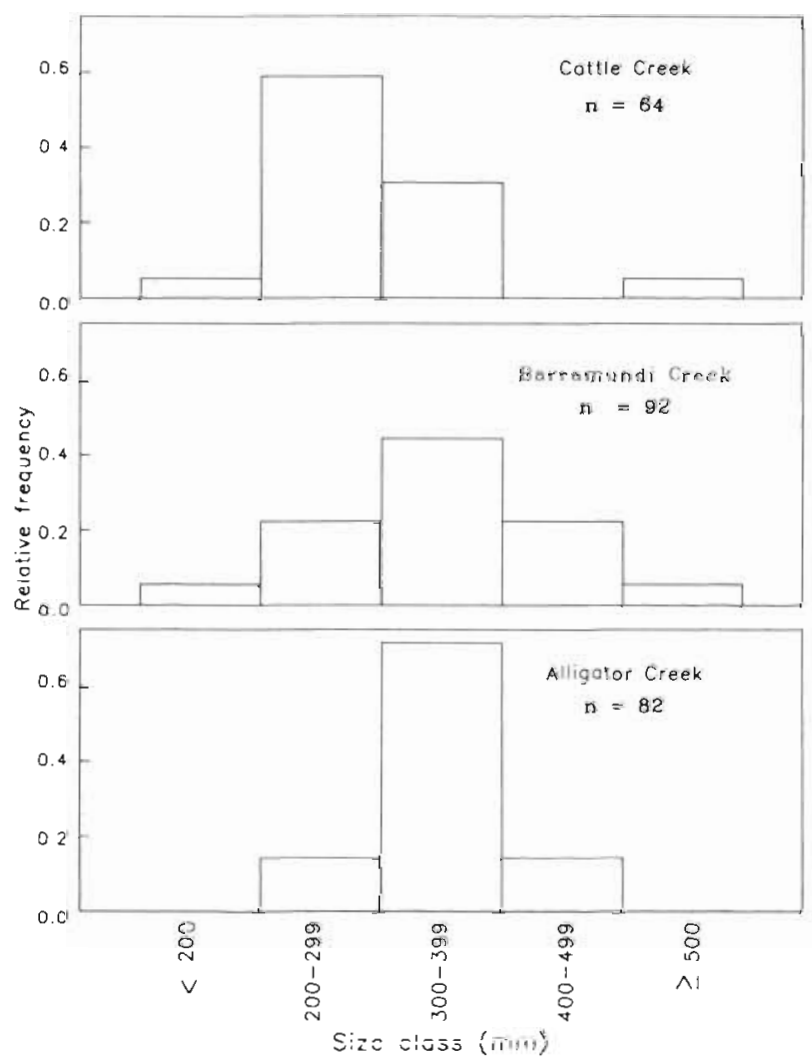

Fig. 7. Epinephelus malabaricus. Size frequency plots for the comparison of the fork lengths of individuals shown in Fig. 6 
the modal size was larger in Barramundi Creek with a higher proportion of fish in the larger size classes. While the modal fork length was similar in Barramundi and Alligator Creeks, Barramundi Creek had a greater proportion of large fish.

\section{Analysis of the distribution and abundance}

For both the comparison of numbers in 4 regions of Cattle and Barramundi Creeks (Analysis l) and the comparison of numbers in 2 regions of Cattle, Barramundi and Alligator Creeks (Analysis II) log-linear modelling yielded the same final model (Table 3 ). This was composed of 2-way interactions between each of the 3 factors. The numbers of the 2 species differed between both Creeks and Regions independently, and Creeks and Regions interacted in the same way for both species.

For the Species by Creek interaction in Analysis I (Table 3a) the numbers of both Epinephelus coioides and E. malabaricus were greater in Barramundi Creek than Cattie Creek (Fig. 8a). Furthermoro, in Cattle Creek the numbers of E. malabaricus were signifi- cantly greater than the numbers of $E$. coioides, while in Barramundi Creek there was no clear evidence that numbers of the 2 species were different. For Analysis II (Table 3b). while more E. malabaricus than. E. coioides were trapped in Cattle Creek, E. coioides was trapped in greater numbers than E. malabaricus in Alligator Creek (Fig 8b). Both were trapped in similar numbers in Barramundi Creek. While numbers of E. malabaricus were similar between the 3 creeks, the numbers of E. coioides were significantly lower in Cattle Creek than in the other 2 creeks (Fig. 8b).

For the Species by Region interaction, in Analysis I (Table 3a) partitioning of deviance showed that the proportions of the 2 species trapped did not differ significantly between the Lower, Upper and Top regions (deviance $=3.295,2 \mathrm{df}_{i} \mathrm{p}=0.19253$ ) with 2 to 3.5 times more Epinephelus malabaricus than $E$. coioides trapped in these regions (Fig. 9a). The bulk of the deviance in the interaction was between these 3 regions (Lower, Upper, Top) and the Bottom region (deviance $=17.371 ; 1 \mathrm{df} ; \mathrm{p}=0.00003$ ) where numbers of the 2 species were similar (Fig. 9a). The numbers of $E$. coioides fell consistently from downstream parts of the creeks to upstream parts; however, after an initial

Table 3. Stepwise fitting (backwards elimination) of log-lınear models for the numbers of Epinephelus coioides and E. malabaricus in 3 estuaries. (a) Four regions in Cattle and Barramundi Creeks (Analysis I), (b) two regions in Cattle, Barramundi and Alligator Creeks (Analysis II). The 3 left-hand columns show the models fitted, and the associated deviance and degrees of freedom. The centre column shows the codes for the current model and the more complex model being compared. The 3 right-hand columns show changes in deviance ( $\Delta$ Deviance), changes in the degrees of freedom ( $\Delta \mathrm{df}$ ) and the probability that the more simple model fits the data adequately. Models containing interactions also contain the main effects composing the interaction. The final model is the model from which no term can be removed without a significant increase in deviance. O: code for the full 3-way model (deviance $=0, \mathrm{df}=0$ ). * denotes the final model

\begin{tabular}{|c|c|c|c|c|c|c|}
\hline Model & Deviance & $\mathrm{df}$ & Comparison & $\Delta$ Deviance & $\Delta \mathrm{df}$ & Probability \\
\hline \multicolumn{7}{|l|}{ (a) } \\
\hline $\begin{array}{l}\text { (A.) Species } \times \text { Creek }+ \\
\text { Species } \times \text { Region }+ \\
\text { Creek } \times \text { Region }\end{array}$ & 2.09 & 3 & $A-O$ & 2.09 & 3 & 05549 \\
\hline (B) Species $\times$ Creek + & & & & & & \\
\hline $\begin{array}{l}\text { Species } \times \text { Region } \\
\text { (C) Species } \times \text { Creek }+\end{array}$ & 12.62 & 6 & $B-A$ & 10.53 & 3 & 0.0145 \\
\hline Creek $\times$ Region & 26.64 & 6 & $\mathrm{C}-\mathrm{A}$ & 24.55 & 3 & 0.0000 \\
\hline Creek $\times$ Region & 32.01 & 4 & $D-A$ & 29.92 & 1 & 0.0000 \\
\hline (E) No 2-way interaction & 59.33 & 10 & $E-A$ & 57.24 & 7 & 0.0000 \\
\hline (b) & & & & & & \\
\hline $\begin{array}{l}\text { (A) Species } \times \text { Creek }+ \\
\text { Species } \times \text { Region }+\end{array}$ & & & & & & \\
\hline $\begin{array}{l}\text { Creek } \times \text { Region * } \\
\text { (B) Species } \times \text { Creek }+\end{array}$ & 2.87 & 2 & $\mathrm{~A}-\mathrm{O}$ & 2 & 2.87 & 0.2377 \\
\hline $\begin{array}{l}\text { Species } \times \text { Region } \\
\text { (C) } \text { Species } \times \text { Creek }+\end{array}$ & 14.17 & 4 & $B-A$ & 2 & 11.30 & 0.0035 \\
\hline $\begin{array}{l}\text { Creek } \times \text { Region } \\
\text { (D) Species } \times \text { Region }+\end{array}$ & 26.28 & 3 & $C-A$ & 1 & 23.41 & 0.0000 \\
\hline Creek $\times$ Region & 42.54 & 4 & $D-A$ & 2 & 39.67 & 0.0000 \\
\hline (E) No 2-way interaction & 69.47 & 7 & $E-A$ & 5 & 66.60 & 0.0000 \\
\hline
\end{tabular}



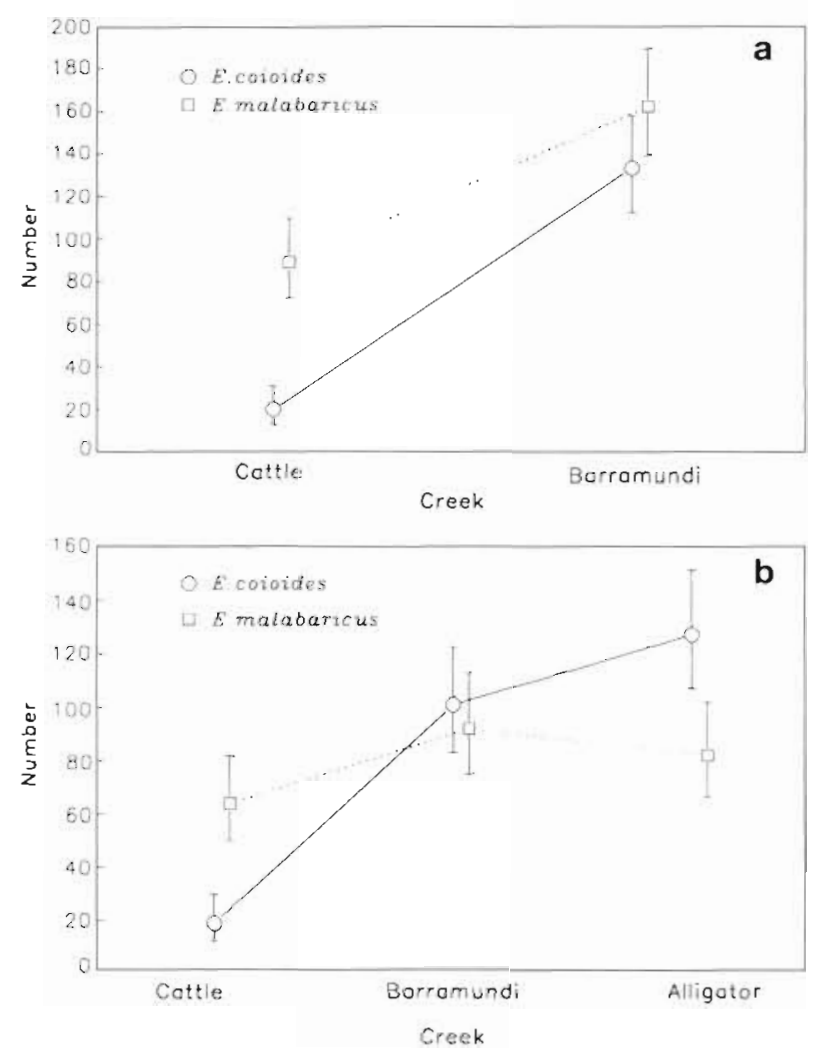

Fig. 8. Effect of the interaction between Species and Creek on the numbers of Epinephelus coioides and E malabaricus in (a) the 4 regions of Cattle and Barramundi Creeks and (b) the 2 seaward regions of Cattle, Barramundi and Alligator Creeks. Data are estimates from the log-linear model $\pm 95 \%$ confidence intervals

increase in numbers from the Bottom region to the Lower region, the numbers of E. malabaricus also declined with distance upstream (Fig. 9a). In Analysis II (Table $3 b$ ), the numbers of E. coioides were similar in both regions and in the Bottom region were greater than the numbers of E. malabaricus (Fig. 9b). The numbers of E. malabaricus increased substantially from the Bottom region to the Lower region, where they were greater than the numbers of E. coioides (Fig. 9b).

For Analysis I (Table 3a) the interaction between Creeks and Regions (independent of species) reflects differences in proportions of Epinephelus spp. between regions in the 2 creeks. Notwithstanding this interaction, the numbers of Epinephelus spp. in each region of Cattle Creek were consistently lower than in the same region of Barramundi Creek (Fig. 10a). Furthermore, there is an overall similarity in the pattern of change between regions for both creeks. In both cases the numbers of Epinephelus spp. tended to be similar in the Dotiun aud Lower regions before talling away successively in the Upper and Top regions (Fig. 10a). In Analysis II (Table 3b) the numbers of Epinephelus spp. in Cattle Creek were similar in both seaward regions and substantially lower than in either Barramundi or Alligator Creeks (Fig. 10b). The numbers of Epinephelus spp. were not clearly different between the Bottom regions of Barramundi and Alligator Creeks, and while there was some evidence that the numbers in the Lower regions were higher for Alligator Creek than Barramundi Creek, the difference was not clear (Fig 10b). As in Cattle Creek the numbers of Epinephelus spp. were very similar in the 2 regions of Barramundi Creek, but in Alligator Creek were greater in the Lower region than in the Bottom region.

\section{Relationship between physical variability and catches}

The overall mean, minimum and maximum water temperatures were similar for all 3 creeks, and at any one time the mean temperature differed relatively little between sampling sites within an estuary. Cattle Creek exhibited low salinities (approx. 0 to $39 \%$; mean
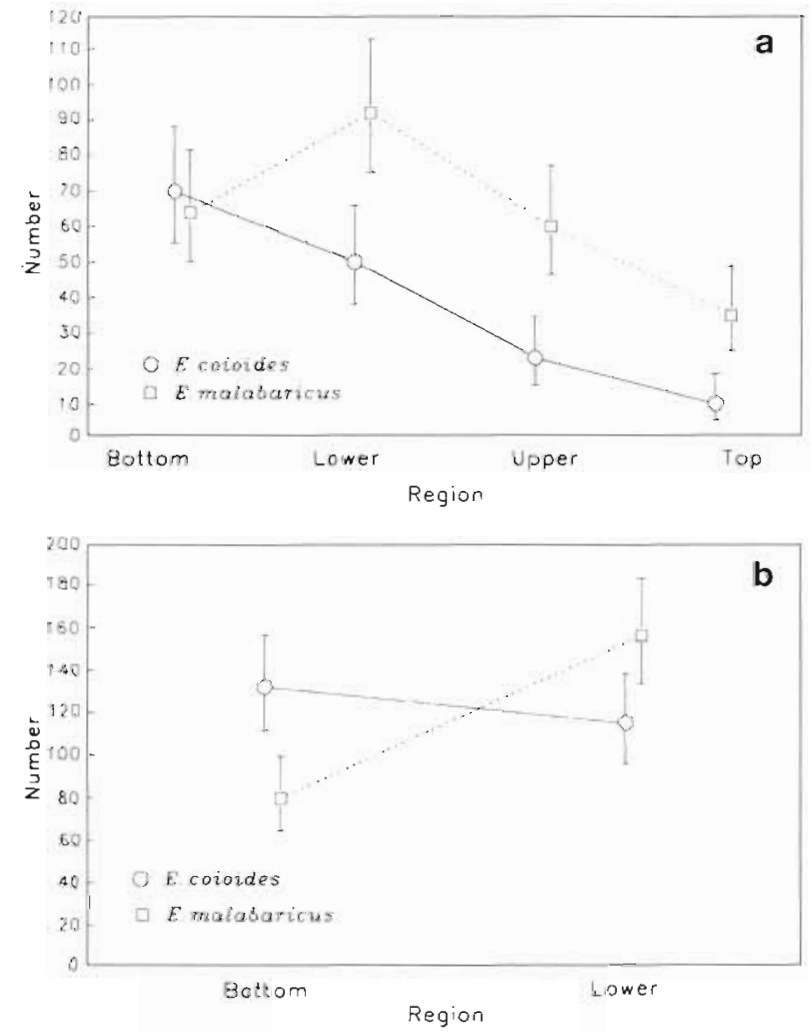

Fig. 9. Effect of the interaction between Species and Region on the numbers of Epinephelus coioides and E. malabaricus in (a) the 4 regions of Cattie aind iond1 anuncii Creeks and (b) the 2 seaward regions of Cattle, Barramundi and Alligator Creeks. Data are estimates from the log-linear model $\pm 95 \%$ confidence intervals 

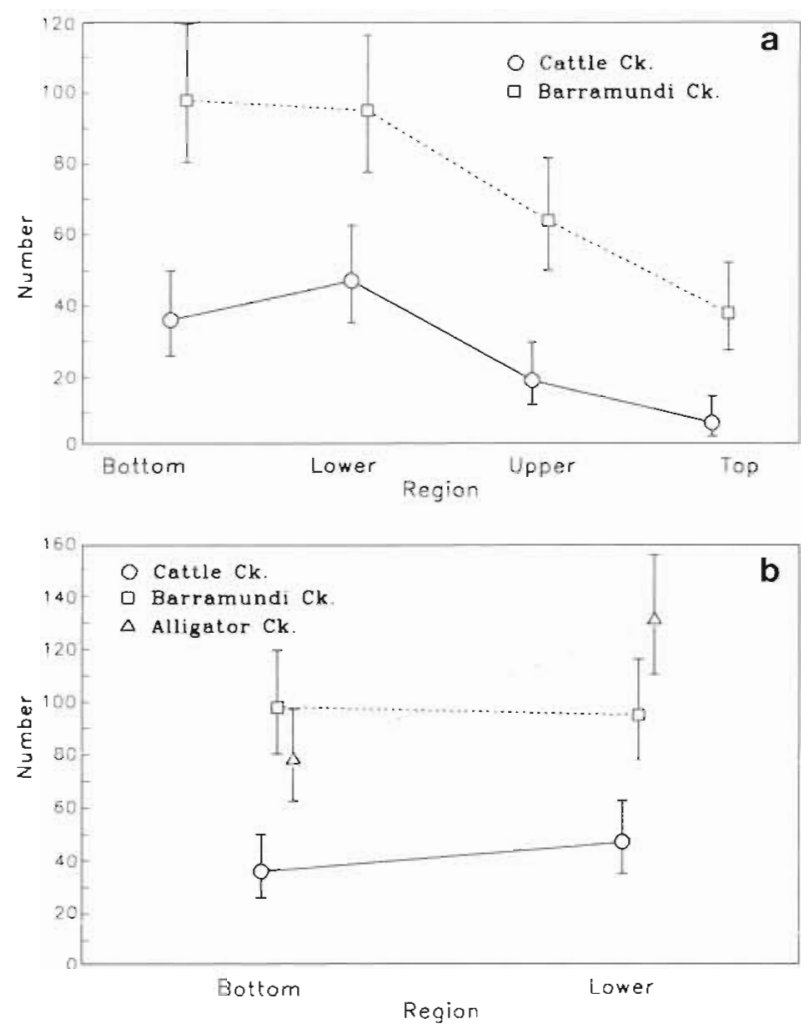

Fig. 10. Effect of the interaction between Creek and Region on the numbers of Epinephelus spp. in (a) the 4 regions of Cattle and Barramundi Creeks and (b) the 2 seaward regions of Cattle, Barramundi and Alligator Creeks. Data are estimates from the $\log$-linear model $\pm 95 \%$ confidence intervals

$27.9 \%$ ) with both mean and minimum salinities well below 'normal' seawater levels. This was due to continual freshwater inputs from stream flow and flooding in Autumn of each year. Lacking major freshwater inputs during the study period, Barramundi Creek exhibited high salinities (approx. 27 to $55.5 \%$; mean $41.6 \%$ ), with both mean and maximum salinities well above 'normal' seawater levels. Alligator Creek's salinities fell between these extremes.

There was no significant correlation between catch rates of either Epinephelus coioides or E. Malabaricus and water temperature (Table 4). While catches of $E$. coioides per rection of each creek per day were significantly correlated with bottom salinity, catches of E. malabaricus were not (Table 4). Howcver, the correlations between catches of both species and the maximum deviation in salinity away from normal seawater (MSD) were much stronger (Table 4).

Catches of Epinephelus coioides per region declined with MSD both above
(Barramundi Creek) and below (Cattle Creek) normal seawater salinity (Fig. 11a). For both positive (Barramundi Creek) and negative (Cattle Creek) MSDs, catches of E. malabaricus first increased then decreased as MSD became greater (Fig. 11b). This pattern was clearer for Cattle Creek than Barramundi Creek where the catch rates for the 3 seaward regions were similar In Alligator Creek, MSD in the 2 regions deviated from normal seawater in opposite directions so the relation between $\mathrm{MSD}$ and catch rates is unclear
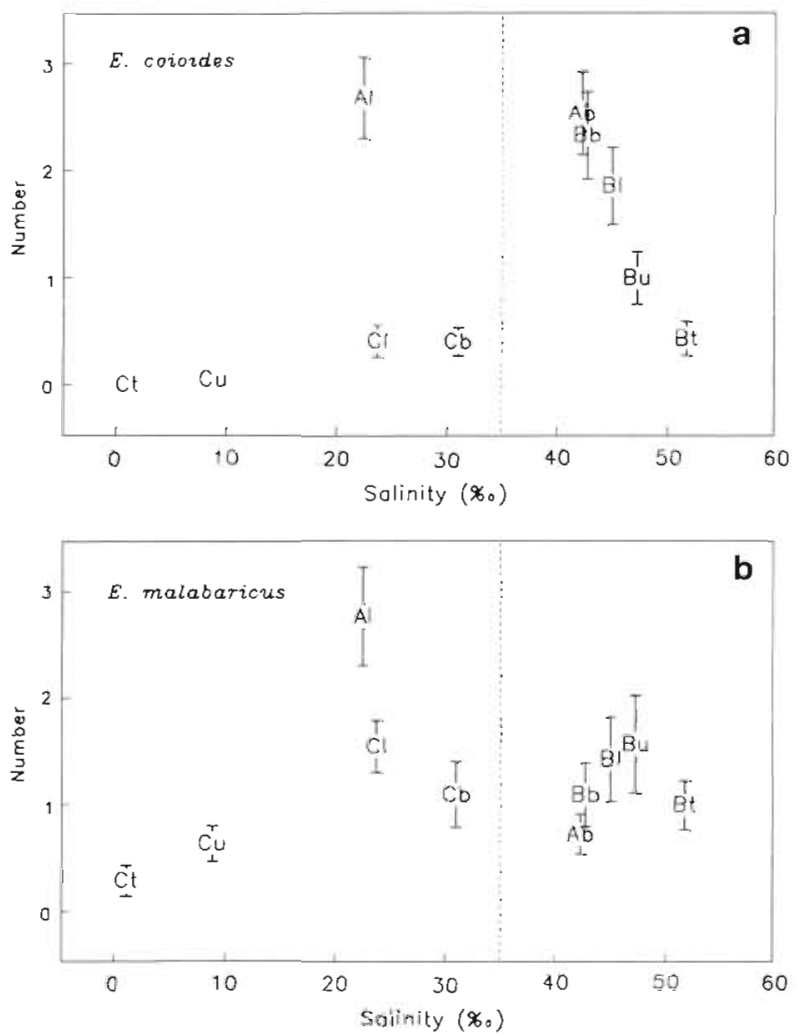

Fig. 11 Relationship between maximum salinity deviation (MSD) and numbers of (a) Epinephelus coioides and (b) E. malabaricus, trapped per region (b, Bottom; l, Lower; $\mathrm{u}$, Upper; t, Top) in Cattle (C), Barramundi (B) and Alligator (A) Creeks. Data are mean numbers per region per day $\pm 95 \%$ confidence intervals. Vertical dashed line represents normal salinity $(35 \%)$

Table 4. Correlations between numbers of Epinephelus coioides and E. malabarıcus caught per trap and bottom temperature $\left({ }^{\circ} \mathrm{C}\right)$, bottom salinity $(\%)$ and maximum deviation in bottom salinity per region. Data presented are the Pearson product moment correlation coefficient ( $r$ ) and its associated probability Ievel $(\mathrm{p}) ; \mathrm{n}=240$

\begin{tabular}{|c|c|c|c|c|c|}
\hline & \multicolumn{2}{|c|}{ Temperature } & \multicolumn{2}{|c|}{ Salinity } & Salinity deviation \\
\hline & r & (p) & $r$ & (p) & r $\quad(p)$ \\
\hline E. coioides & 0.0423 & $(0.5143)$ & 0.1572 & $(0.0148)$ & $-0.3623(0.0000)$ \\
\hline E. malabaricus & 0.1038 & $(0.1087)$ & 0.0930 & $(0.1509)$ & $-0.1824(0.0046)$ \\
\hline
\end{tabular}




\section{DISCUSSION}

\section{Comparison of the distribution and abundance}

The abundances of Epinephelus spp. varied between estuary systems. Greater numbers of both $E$. coioides and E. malabaricus were trapped in Barramundi Creek than in Cattle Creek (Fig. 8a), and catches of $E$. Coioides in the 2 seaward regions of Cattle Creek were substantially lower than in these regions in the other 2 creeks (Fig. $8 \mathrm{~b}$ ). It is possible that the observed low abundances in Cattle Creek may reflect a fundamental difference between this and the other 2 creeks. If so, it would appear that in some way Cattle Creek provides a poorer quality of habitat than Barramundi and Alligator Creeks. One factor that could contribute to the low abundances in Cattle Creek is the occurrence of regular, annual floods. Flooding can influence abundances of estuarine fish populations both directly (Marais 1982, 1983), and indirectly by its influence on salinity (Hoff \& Ibara 1977. Marais 1988, Moser \& Gerry 1989), which is important in structuring fish communities in tropical estuaries (Quinn 1980). During the present study annual flooding of Cattle Creek caused a marked depression of salinity compared to the other 2 creeks. This annual influx of fresh water and the associated salinity reduction could work in a variety of ways to reduce numbers of the 2 species. Hyposaline conditions would cause osmoregulatory problems (Lasserre 1975, Martin 1988) perhaps increasing mortality rates (Lockwood 1976) or causing fish to move to other areas (Hoese 1960). Low salinity and increased stream flow during flooding may prevent many recruits from entering the creek or at least penetrating upstream areas, or cause newly settled fish to be flushed from the creek. Increased outflow from the creek and associated reduction in salinity may reduce the abundance of prey organisms (Cyrus 1988), thereby reducing the amount of food available to Epinephelus spp. If the extra freshwater input to Cattle Creek did affect the abundance of Epinephelus spp., the fact that $E$. malabaricus was trapped in greater abundance than E. coioides in Cattle Creek but not in the other creeks suggests that E. malabaricus may possess greater tolerances to reduced salinity levels.

Despite the plausibility of explanations involving differences in salinity or flooding regimes there are other possible reasons for the changes in abundance of Epinephelus spp. between estuaries. It may be that the differences in abundance were specific to the time window in which the study was conducted and not a reflcction of loñy-tenu paiterns. For instance, unusually poor recruitment in Cattle Creek over a number of years while the other creeks received normal or better than normal recruitment could have produced the observed differences.

In both Cattle and Barramundi Creeks, there was a strong trend for the numbers of both species of Epinephelus to decline in an upstream direction (Fig. 10a). Notwithstanding this, the pattern was different for the 2 species. In the seaward regions of Cattle and Barramundi Creeks the numbers of $E$. coioides and $E$. malabaricus were very similar. However, while the numbers of $E$. coioides fell consistently with distance upstream, the numbers of E. malabaricus first increased substantially in the Lower region, and while they did fall consistently in the 2 upstream regions they remained significantly higher than the numbers of $E$. coioides (Fig. 9a). When data for Alligator Creek were included and only the 2 seaward regions considered, a change in the dominance of the 2 species was seen, with E. coioides more abundant in the most seaward (Bottom) regions and E. malabaricus more abundant in the Lower region (Fig 9b). Although using somewhat different spatial divisions, previous studies of Alligator Creek (Sheaves 1992) also found that E. coioides was more abundant in downstream parts and $E$. malabaricus more abundant in upstream parts.

While there were clear differences between the spatial abundances of the 2 species, the reasons for these differences are unclear It may be that Epinephelus malabaricus recruits are better able to access upstream areas than recruits of $E$. coioides, leading to higher recruitment. Alternatively, habitat types, food availability or physical conditions may be less favourable in upstream areas. For instance, while the seaward regions of both Cattle and Barramundi Creeks (where similar abundances of the 2 species occurred) exhibited salinity levels close to that of 'normal' seawater, salinity levels deviated markedly from 'normal' seawater salinity in the upstream regions of both Cattle and Barramundi Creeks. In these areas E. malabaricus became the dominant species. This occurred in both creeks despite the deviation from 'normal' salinity being in opposite directions (hyposaline in Cattle Creek, hypersaline in Barramundi Creek). It may be that E. malabaricus is more tolerant to variations in salinity away from 'normal' seawater levels than is $E$. coioides. Differences in physical tolerances can be important in causing closely related species of estuary fish to exhibit different patterns of distribution and abundance (Martin 1988), and it is not uncommon for both hypersaline and hyposaline conditions to lead to reduced abundances (Gunter 1961). Indeed the catch rates of both species of Epinephelus were correlated with the maximum deviation in salinity (MSD) rather than salinity per se. This suggests that if salinity, or some correlated variable, does influence the abundance of the 2 species it is through long-term effects 
rather than short-term changes. Clearly, if a long-lived fish cannot cope with particular salinity levels, a short period of adverse conditions may kill the fish or cause it to migrate away, thereby influencing patterns of abundance for a considerable time into the future. However, the link between catch rates and MSD does not establish causality, only correlation. Many other variables (e.g. water depth and distance from the ocean) also correlate with MSD. Even if the long-term pattern of salinity deviation is a major factor controlling the abundance of Epinephelus spp. the relationship is unlikely to be as simple as a direct correlation with MSD. Factors such as the duration and regularity of salinity variation (Lockwood 1976) would probably be as im.portant as the actual deviation from 'normal' salinity.

\section{Comparison of size structures}

Over the 3 creeks sampled, the size structures of the 2 Epinephelus species demonstrated some marked differences. Both the modal and maximum lengths of $E$. malabaricus were largor than those of $E$. coinides. For both species there was a sharp decline in numbers caught at the lower ends of the size distributions, with few fish below $120 \mathrm{~mm}$ trapped. This was well above the minimum size that could have been retained by the $12.5 \mathrm{~mm}$ mesh, as the maximum body depth of a $120 \mathrm{~mm}$ E. coioides is about $28 \mathrm{~mm}$ (pers. obs.). Thus the traps should have been able to catch much smaller Epinephelus spp. than they did. It appears therefore, that either the smaller fish occupied habitats that were not sampled, or if present in the sampling area, that they exhibited behaviours that meant that they did not enter the traps. If small, juvenile Epinephelus spp. do use different habitats to the larger fish it is not clear what these may be. A number of studies have reported Epinephelus spp. from coastal seagrass habitats (Blaber et al. 1989, 1992). However, in each case insufficient data are available to determine if small juveniles were common. Conversely, no species of Epinephelus were recorded from beam trawl samples ( $2 \mathrm{~mm}$ mesh net) from seagrass beds adjacent to Trinity Inlet in northeastern Australia (Coles et al. 1993). Thus it is unclear if small juvenile $E$. coioides or $E$. malabaricus utilise seagrass habitats to a substantial extent. While there are other habitats that could be used by small, juvenile E. coioides and E. malabaricus, no study of these habitats has reported significant numbers of small juveniles of either species.

No clear spatial or temporal differences were found in the length of Epinephelus coioides. This may well have been due to a lack of data preventing viable analysis of $E$. coioides length for many spatio-temporal combinations.
The mean length of Epinephelus malabaricus was greater in the 2 seaward regions of Barramundi Creek than in the 2 seaward regions of either Cattle or Alligator Creeks. The reasons for this difference are not clear These differences in size structure may be a reflection of different settlement histories. For instance, settlement may have been more successful in Barramundi Creek than in the other 2 creeks in the years when the large individuals now present were recruited. However, the mean length of E. malabaricus for the Upper region of Cattle Creek was greater than for the Upper region of Barramundi Creek (Fig. 4), making arguments of differentid settlement success between creeks difficult to sustain. Apparently more complex explanations, including mechanisms producing within-creek differences, are needed to account for the patterns of spatial differences in length of E. malabaricus

Epinephelus coioides and E. malabaricus are closely related species. Both are similar in appearance, occupy the same habitats and are represented in estuaries almost entirely by iuveniles (Sheaves 1995b). Despite these similarities, the 2 species showed very different patterns of distribution and abundance, both within and between estuaries. In seaward parts of the estuaries the numbers of $E$. coioides were similar to or greater than those of E. malabaricus. However, in upstream areas E. malabaricus became much more abundant than E. coioides. This change in dominance may relate to differences in the abilities of settling juveniles to access upstream areas. Conversely, it may be that the 2 species differ in their ability to deal with the extreme physical conditions that occur in upstream parts of these estuaries. Regardless of the reason, these spatial differences in abundance suggest that E. malabaricus is better equipped to deal with the challenges of estuary life than $E$. coioides.

Acknowledgements. I thank all those who assisted in this project. My particular thanks goes to the Maynard family who provided access to Cattle Creek. I also extend special thanks to B. Molony, G. Russ and D. Williams for their invaluable advice and support during this project.

\section{LITERATURE CITED}

Blaber SJM, Brewer DT, Salıni JP (1989) Species composition and biomasses of fishes in different habitats of a tropical northern Australian estuary: their occurrence in the adjoining sea and estuarine dependence. Estuar Coast Shelf Sci 29:509-531

Blaber SJM, Brewer DT, Salini JP, Kerr J, Conacher C (1992) Species composition and biomasses of fishes in tropica. seagrasses at Groote Eylandt, northern Australı. Estuar Coast Shelf Sci 35:605-620 
Blaber SJM, Young JW, Dunning MC (1985) Community structure and zoogeographic affinities of the coastal fishes of the Dampier region of north-western Australia. Aust $J$ Mar Freshwat Res 36:247-266

Bonell M (1983) Wet tropical coast of north-east Queensland, Australia. Report prepared for the UNESCO IHP Project A.1.10. Hydrology of humid tropical regions: sub-project A.1.10.3. James Cook University, Townsville

Coles RG, Lee Long WJ, Watson RA, Derbyshire KJ (1993) Distribution of seagrasses, and their fish and penaeid prawn communities, in Cairns Harbour, a tropical estuary, northern Queensland, Australia. Aust J Mar Freshwat Res 44:193-210

Collette BB (1983) Mangrove fishes of New Guinea. In: Teas HJ (ed) Tasks for vegetation science, Vol 8. Dr W Junk Publishers, The Hague, p 91-102

Cyrus DP (1988) Episodic events and estuaries: effects of cyclonic flushing on the benthic fauna and diet of Solea bleekeri (Teleostei) in Lake St Lucia on the south-eastern coast of Africa. J Fish Biol 33(Suppl A):1-7

Gunter G (1961) Some relations of estuarine organisms to salinity. Limnol Oceanogr 6:182-190

Hoese HD (1960) Biotic changes in a bay associated with the end of a drought. Limnol Oceanogr 5:326-336

Hoff JG, Ibara RM (1977) Factors affecting the seasonal abundance, composition and diversity of fishes in a southeastern New England estuary. Estuar Coast Mar Sci $5: 665-678$

Kalle K (1971) Salinity. Generăl introduction. In: Kinne O (ed) Marine ecology, Vol 1, Part 2. Wiley-Interscience, Sydney, p 683-703

Lasserre P (1975) Osmoregulatory responses to estuarine conditions: chronic osmotic stress and competition In: Wiley $M$ (ed) Estuarine processes, Vol I, Stress and adaptation to the estuary. Academic Press, sew York, p $395-409$

Lockwood APM (1976) Physiological adaptation to life in estuaries. In: Newell RC (ed) Adaptation to environment: essays on the physiology of marine animals. Butterworths, London, p 315-388

Marais JFK (1982) The effects of river flooding on the fish populations of two eastern Cape estuaries. S Afr J Zool 17 : 96-104

Marais JFK (1983) Fish abundance and distribution in the Gamtoos estuary with notes on the effect of floods. S Afr J Zool 18:103-109

This article was presented by D. M. Alongı (Senior Editorial Advisor), Townsville, Australia
Marais JFK (1988) Some factors that influence fish abundance in South African estuanes. S Afr J Mar Sci 6:67-77

Martin TJ (1988) Interaction of salinity and temperature as a mechanism for spatial separation of three co-existing species of Ambassidae (Cuvier) (Teleostei) in estuaries on the south-east coast of Africa. J Fish Biol 33(Suppl A):9-15

Moser ML, Gerry LR (1989) Differential effects of salinity changes on two estuarine fishes, Leiostomus xanthurus and Micropogonias undulatus. Estuaries 12(1):35-41

Oliver J (1978) The climatic environment of the Townsville area. In: Hopley D (ed) Geographical studies of the Townsville area. Department of Geography, James Cook University of North Queensland, Monograph Series: Occasional Paper No 2, p 3-17

Quinn NJ (1980) Analysis of temporal changes in fish assemblages in Serpentine Creek, Queensland. Environ Biol Fish 5(2):117-133

Randall JE (1987) A preliminary synopsis of the groupers (Perciformes: Serranidae: Epinephelinae) of the IndoPacific region. In: Polovina JJ, Rolston S (eds) Tropical snappers \& groupers: biology and management. Westvıew Press, Boulder, CO, p 89-188

Randall JE, Allen GR, Steene RC (1990) Fishes of the Great Barrier Reef and Coral Sea. Crawford House Press, Bathurst

Randall JE, Ben-Tuvia A (1983) A review of the groupers (Pisces: Serranidae: Epinephelinae) of the Red Sea, with description of a new species of Cephalopholis. Bull Mar Sci 33(2):373-426

Randall JE, Heemstra PC (1991) Revision of Indo-Pacific Groupers (Perciformes: Serranidae: Epinephelnae), with descriptions of five new species. Bernice Pauahi Bishop Museum, Honolulu

Sheaves MJ (1992) Patterns of distribution and abunclance of fishes in different habitats of a mangrove-lined tropical estuary, as determined by fish trapping. Aust J Mar Freshwat Res 43(6): 1461-1479

Sheaves MJ (1993) Patterns of movement of some fishes within an estuary in tropical Australia. Aust J Mar Freshwat Res 44:867-880

Sheaves MJ (1995a) Effect of design modifications and soak time variations on Antillean- $Z$ fish trap performance in a tropical estuary. Bull Mar Sci 56(2):475-489

Sheaves MJ (1995b) Large lutjanid and serranid fishes in tropical estuaries: are they adults or juveniles? Mar Ecol Prog Ser 129:31-40

Manuscript first received: May 30, 1995

Revised version accepted: January 9, 1996 